\title{
Методичні рекомендації щодо загального планування об'єднаної підготовки військ (сил) оперативного (повітряного, морського) командування
}

\author{
Володимир Баталюк * 1 А; Дмитро Купрієнко ${ }^{2}$ в ; Григорій Тіхонов 3 А \\ А Національний університет оборони України імені Івана Черняховського, м. Київ, Україна

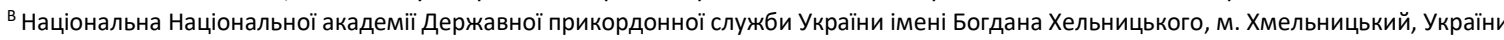

Received: October 7, 2021 | Revised: October 20, 2021 | Accepted: October 30, 2021

DOI: $10.33445 /$ sds.2021.11.5.15

\begin{abstract}
Анотація
Стаття присвячена плануванню підготовки органів військового управління та військових частин, пріоритетам в діяльності штабів на оперативному і тактичному рівнях управління у зв'язку з переходом на нові структури (НАТО) органів військового управління ЗС України. Розглянуті сучасні проблеми планування підготовки в оперативних штабах, який входить до штабу оперативного командування (ОК), а планування бойової підготовки управлінь (відділів), які підпорядковані безпосередньо командувачу оперативного командування.
\end{abstract}

Ключові слова: оперативне (повітряне, морське) командування, планування об'єднаної підготовки, план підготовки, спроможності.

\section{Постановка проблеми}

Для якісного планування підготовки складових сил оборони держави в першу чергу стоїть завдання налагодити процес планування підготовки, який на відміну від існуючого повинен поєднати в собі підготовку у видах (окремих родах військ (сил) 3С України, підготовку в підрозділах інших військових формувань та правоохоронних органах (ІВФ та ПрО) та об'єднану підготовку сил оборони держави (СОД) [1-10]. Такий підхід дозволить забезпечити набуття спроможностей та об'єднаних спроможностей.

\section{Аналіз останніх досліджень та публікацій}

Проблемами удосконалення системи підготовки військові науковці займались постійно. Вагомий вклад в розвиток планування бойової підготовки зробили Ю.Є. Репіло, В. В. Хома, С. Г. Пехота.

Репіло Ю. Є. запропонував методику, яка враховує вичерпну роль ОВУ в процесі планування підготовки, але не враховує особливостей планування об'єднаної підготовки СОД [10].

Хома В. В запропонував методику, яка пропонує математичну модель, що враховує підготовку в ЗС України та об'єднану підготовку сил оборони [11].

Рекомендації розроблені Пехотой С. Г. щодо організації і проведення індивідуальної підготовки офіцерів бригади тактичної авіації, спрямовані на набуття індивідуальних спроможностей офіцерами успішно виконувати визначенні завдання не враховують особливостей набуття індивідуальних спроможностей виконувати завдання в складі об'єднаних військових формувань сил оборони держави [12].

Аналіз праць вищеперерахованих науковців свідчить, що вказані науковці не

\footnotetext{
1 * Corresponding author: доцент кафедри, e-mail: 0503172161@ukr.net

2 доктор військових наук, професор, e-mail: dakupriyenko@gmail.com

${ }^{3}$ кандидат військових наук, старший науковий співробітник, начальник кафедри, e-mail: kss2014@ukr.net
} 
розглядали в процесі планування поєднання підготовки військових частин (підрозділів) 3 С України з IBФ та ПрО і не розглядали можливості використання поетапної системи планування підготовки складових сил оборони.

\section{Постановка завдання}

Зміни в системі підготовки СОД, відсутність єдиних поглядів між суб'єктами підготовки різних відомств СОД щодо порядку Виклад основного матеріалу

Відповідно до чинних керівних документів [1-6] планування об'єднаної підготовки військ (сил) ОК є процесом визначення мети, завдань та сукупності узгоджених заходів підготовки, які необхідні для послідовного набуття об'єднаних оперативних (бойових, спеціальних) спроможностей при ефективному використанні виділених ресурсів.

Загальний порядок та послідовність планування підготовки військ (сил) ОК здійснюється на підставі Доктрини “Організація об'єднаної підготовки сил оборони держави” (2020р.) та Методичних рекомендацій ГШ ЗС України, затверджених начальником ГШ ЗС України (2020р.).

Планування об'єднаної підготовки ОК здійснюється у загальній системі планування підготовки військ (сил) ОК та планування підготовки (службової діяльності) органів управління та військових частин ICCO на навчальний рік.

Планування підготовки ОВУ, військ (сил) 3С України включає середньострокове та короткострокове планування $[1,2,3,7,8]$.

Оперативне командування здійснює короткострокове планування підготовки ОВУ та військових частин.

Короткострокове планування об'єднаної підготовки військ (сил) ОК - це колективна робота штабу ОК, штабів військових частин, органів управління ICCO щодо визначення мети та завдань підготовки, кількості, порядку та послідовності, районів (місць) і часу проведення заходів об'єднаної підготовки військ (сил) та завдань щодо їх всебічного забезпечення на навчальний рік.

Орієнтовний перелік основних заходів об'єднаної підготовки військ (сил) та основних досягнення об'єднаних спроможностей, спонукало на розробку рекомендацій щодо планування підготовки та їх обґрунтування. оперативних (бойових, спеціальних) завдань (спроможностей) на навчальний рік, а також сили і засоби ICCO, які до них залучаються, розробляються Генеральним штабом ЗС України (структурним підрозділом J7). Цей перелік до 1 червня поточного року надається до ОK та органів управління ICCO для врахування під час планування заходів підготовки військ (сил) і повсякденної діяльності на наступний навчальний рік.

Короткострокове планування поділяється на загальне та поточне планування.

Під час загального планування підготовки військ (сил) ОК в планувальних документах уточнюються і узгоджуються завдання, цілі і заходи підготовки на наступний навчальний рік з урахуванням орієнтовного (прогнозованого) розподілу видатків на підготовку.

Організація загального планування об'єднаної підготовки військ (сил) ОК.

Загальне керівництво плануванням об'єднаної підготовки військ (сил) здійснює командувач ОК, безпосереднє - начальник штабу (заступник командувача).

Планування об'єднаної підготовки ОК організовується управлінням підготовки ОК (G-7) та відділом оперативної підготовки штабу ОК. До проведення заходів планування залучаються об'єднані робочі групи планування підготовки від ОВУ видів, окремих родів військ ЗС України та органів управління ICCO, що дислокуються на території відповідальності ОК для формування конкретного переліку заходів підготовки $[6,10]$.

Процес загального планування підготовки військ (сил) ОК поділяється на три послідовні та взаємопов'язані етапи рисунок $1[4,5,10]$. 


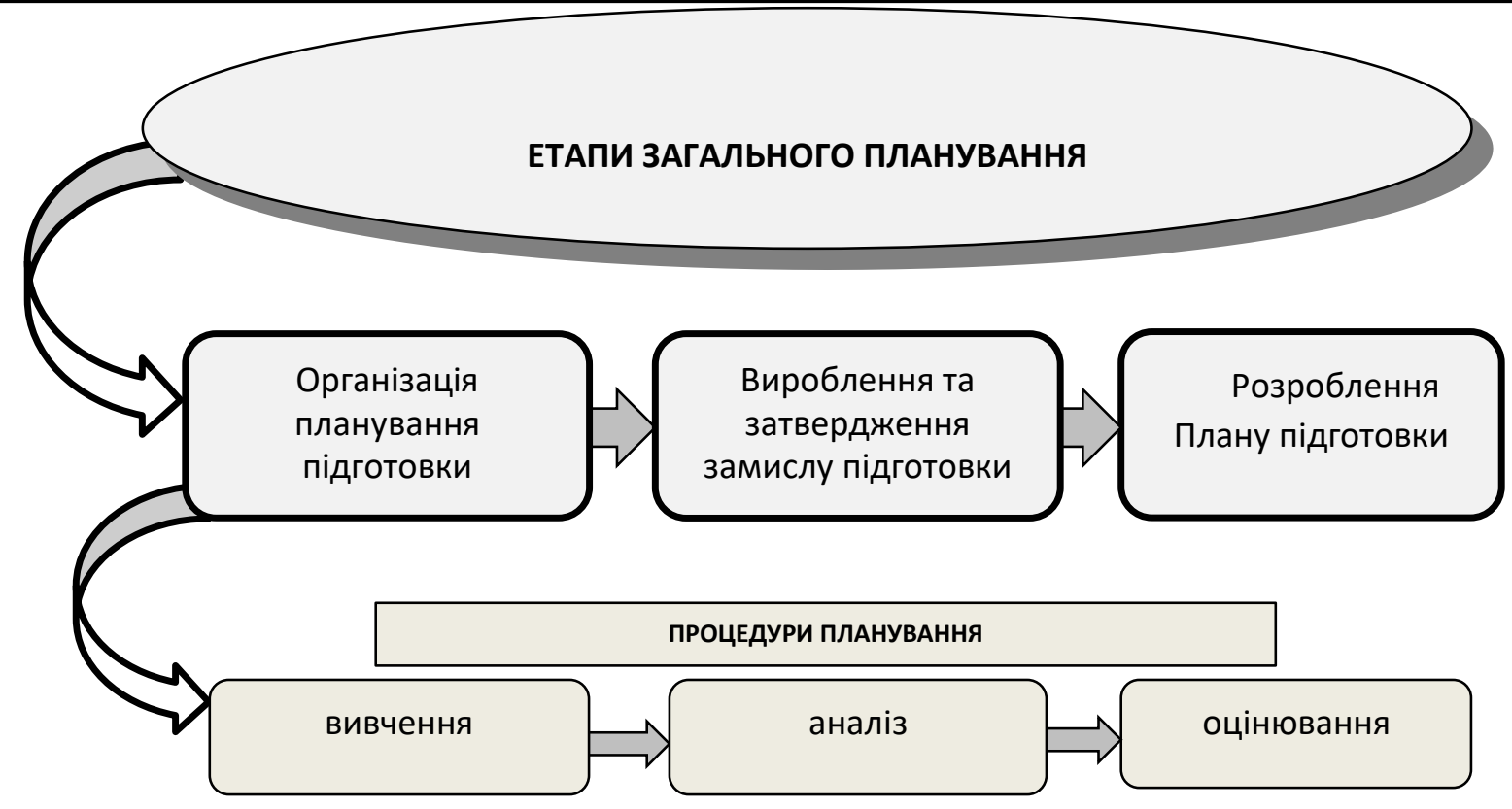

Рисунок 1 - Етапи та процедури загального планування підготовки військ (сил) Ок

Вихідними даними для організації загального планування підготовки військ (сил) ОК є: розпорядження з організації підготовки вищих органів військового управління ЗС України; завдання згідно з оперативними планами застосування військ (сил) ОК; досягнутий рівень злагодженості органу військового управління та військових частин (підрозділів) ОК, (накази з результатами аналізу і оцінювання підготовки); орієнтовні видатки бюджету Міністерства оборони України, що передбачаються для забезпечення потреби на підготовку ОК; накази (розпорядження) командувача військ оперативного командування щодо планування та організації об'єднаної підготовки.

Крім того, в ході проведення планування підготовки військ (сил), повинен враховуватися уточнений перелік реальних та потенційних загроз національній безпеці України у воєнній сферi.

Під час вивчення вихідних даних для планування командувач ОК особисто здійснює наступні заходи:

усвідомлює мету, основні завдання та пріоритети підготовки на наступний навчальний рік, які визначені у директиві Головнокомандувача ЗС України з організації планування підготовки; з'ясовує перелік оперативних (бойових, спеціальних) спроможностей, які необхідно набути підпорядкованим ОВУ та військовим частинам;

вивчає перелік основних заходів підготовки, які проводяться під керівництвом старших начальників;

з'ясовує часові показники (терміни вироблення замислу, розроблення плану підготовки) та інші завдання, які визначені в директивних документах Головнокомандувача ЗС України, начальника ГШ ЗС України та командувача СВ 3 С України $[6,10]$.

Після вивчення вихідних даних, командувач ОК особисто віддає вказівки своїм заступникам та керівникам структурних підрозділів ОК щодо особливостей планування підготовки на наступний навчальний рік. При цьому він вказує (уточняє):

директиви (розпорядження) 3 організації планування підготовки Головнокомандувача ЗС України, Генерального штабу ЗС України та командувача СВ ЗС України;

завдання згідно з оперативними планами застосування; досягнутий рівень злагодженості ОВУ та військових частин ОК (накази 3 результатами аналізу і оцінювання підготовки у поточному році); орієнтовні видатки бюджету Міністерства оборони України, що 
передбачаються для підготовки військ (сил) ОК у наступному році;

витяг із Переліку типових завдань Сухопутних військ Збройних Сил України за сценаріями виникнення та розвитку ситуацій воєнного характеру, в частині, що стосується оперативного командування;

витяг із Єдиного переліку (каталогу) спроможностей Збройних Сил в частині, що стосується оперативного командування та ICCO, що дислокуються на території відповідальності;

програми (стандарти) підготовки родів військ (сил) та спеціальних військ ОК;

першочергові завдання на підготовчий період та основні завдання щодо організації планування підготовки військ (сил) ОК на наступній начальний рік $[6,10]$.

Після відданих вказівок командувачем на планування підготовки військ (сил) ОК, начальник штабу ОК (заступник командувача) конкретизує завдання офіцерам групи планування, основним змістом яких можуть бути:

усвідомлення мети, основних завдань та пріоритетів об' $є$ днаної підготовки на наступний навчальний рік, які визначені у керівних документах вищого ОВУ та вказівках (розпорядженні) командувача ОК щодо організації планування;

з'ясування переліку об'єднаних спроможностей, які необхідно набути ОВУ, військовим частинам ОК та ICCO;

вивчення переліку основних заходів об'єднаної підготовки, які проводяться під керівництвом старших начальників та командувача ОК;

з'ясування часових показників (термінів вироблення і затвердження замислу, розроблення та затвердження плану підготовки) та інші завдання, які визначені директивою Головнокомандувача ЗС України щодо планування підготовки на наступний навчальний рік $[6,10]$.

Крім того, начальник штабу ОК (заступник командувача) уточняє окремі питання, які обов'язково повинні бути враховані під час планування підготовки військ (сил) ОК, а саме: організаційно-штатна структура ОВУ, військових частин і підрозділів, їх укомплектованість особовим складом, ОВТ;

наявність, пропускна спроможність (можливості) об'єктів навчальної матеріальнотехнічної бази для проведення заходів об'єднаної підготовки;

нові способи ведення бойових (стабілізаційних) дій (виконання інших завдань, визначених Міністром оборони України та Головнокомандувачем ЗС України);

прийняття на озброєння нових (модернізованих) зразків озброєння, зброї та військової техніки;

умови побуту особового складу на об'єктах навчальної матеріально-технічної бази;

фізико-географічні та кліматичні особливості операційної зони (районів) в яких передбачено застосування військ (сил) ОК.

3 отриманням завдання (вказівок командувача та НШ ОК), керівники структурних підрозділів командування ОК (начальники родів військ, спеціальних військ та служб) відпрацьовують пропозиції щодо підготовки за своїм напрямом діяльності. Вони розробляються за елементами замислу підготовки і включають формулювання:

мети та основних завдань підготовки;

пріоритетних напрямів підготовки органів військового управління та підпорядкованих військових частин;

основних заходів підготовки, які необхідно провести для забезпечення готовності ОВУ та підпорядкованих військових частин до виконання завдань за призначенням;

першочергових заходів, які необхідно виконати до початку нового навчального року в інтересах організації об'єднаної підготовки військ (сил).

Відповідно до завдань, що поставлені (уточнені) начальником штабу ОК (заступником командувача), під час проведення аналізу вихідних даних, офіцери групи планування вивчають $[6,7,10]$ :

склад підпорядкованих ОВУ і військових частин ОК та органів управління і військових частин (підрозділів) ICCO, що дислокуються в 
зоні відповідальності ОК їх стан та укомплектованість, досягнутий рівень злагодженості за підсумками проведення заходів об'єднаної підготовки протягом поточного року;

стан НМТБ та ї̈ можливості щодо забезпечення процесу набуття ОВУ військовими частинами ОК та органами управління і військовими частинами (підрозділами) ІССО об'єднаних оперативних (бойових, спеціальних) спроможностей;

орієнтовний розподіл видатків, що передбачаються для забезпечення потреб на об'єднану підготовку ОВУ і військових частин ОК та органів управління і військових частин (підрозділів) ICCO, їx можливість щодо організації та проведення заходів підготовки;

вимоги нормативних та керівних документів, які впливають на організацію та проведення заходів об'єднаної підготовки, забезпечення готовності ОВУ (ОУ), військових частин (підрозділів) ОК та ICCO до виконання завдань за призначенням.

Відповідно до затвердженого графіку відпрацювання основних планувальних документів, у визначений термін командувач ОК особисто заслуховує пропозиції керівників структурних підрозділів ОК (начальників родів військ, спеціальних військ та служб) до замислу об'єднаної підготовки військ (сил) ОК на новий навчальний рік $[6,10]$.

Після вивчення, аналізу та оцінювання вихідних даних, пропозицій службових осіб та вказівок командувача і начальника штабу ОК (заступника командувача), офіцери об'єднаної робочої групи планування підготовки приступають до відпрацювання (вироблення) замислу об'єднаної підготовки військ (сил).

Паралельно (одночасно) з відпрацюванням Замислу підготовки військ (сил) ОК, в органах управління ICCO, що дислокуються в межах відповідальності ОК, розробляється замисел та інші планувальні документи з підготовки ОУ та військових частин ICCO.

В цей період повинна бути налагоджена тісна взаємодія між органами управління (штабами) ОK та ICCO 3 питань організації об'єднаної підготовки. Особисто начальником штабу ОК забезпечується узгодження замислів і планів підготовки (документів з підготовки) ICCO 3 основними планувальними документами підготовки військ (сил) ОК в частині, що стосується підготовки до спільних дій з метою оборони держави.

При цьому, заплановані заходи підготовки та терміни їх проведення обов'язково повинні бути узгоджені із завданнями, визначеними планами застосування військ (сил) ОК та ICCO, а також заходами повсякденної діяльності [6, 10].

Для узгодження заходів об'єднаної підготовки 3 ресурсним забезпеченням проводиться порівняння визначеної потреби в коштах 3 граничними обсягами ресурсів, передбаченими на підготовку військ (сил) ОК та ICCO в наступному році. За результатами порівняння визначаються пріоритети підготовки ОВУ та військових частин і проводиться уточнення переліку заходів підготовки, а також коригуються завдання та показники злагодженості (навченості), які можливо буде досягнути в межах визначених обсягів ресурсного забезпечення.

Одночасно з оформленням замислу підготовки, офіцерами групи планування підготовки, відпрацьовується доповідь командувача ОК старшому начальнику під час затвердження Замислу підготовки військ (сил) ОК, у якій відображаються: мета та основні завдання підготовки; загальний порядок підготовки ОВУ та військових частин ОК, із зазначенням основних заходів підготовки, у тому числі підготовки спеціалістів дефіцитних спеціальностей; очікувані результати на кінець навчального року.

Порядок оформлення Замислу підготовки військ (сил) ОК визначений у Методичних рекомендаціях з планування підготовки у Збройних Силах України. [10]

У визначений директивою Головнокомандувача ЗС України термін командувач (начальник штабу) ОК погоджує Замисел підготовки військ (сил) ОК з Командуванням підготовки Сухопутних військ ЗС України та 
Головним управлінням доктрин та підготовки ГШ зС України.

Після погодження Замислу підготовки військ (сил) ОК командувач ОК затверджує його у командувача Сухопутних військ ЗС України.

Замисли підготовки військ (сил) ОК розробляється та оформлюються у двох примірниках. Затверджений другий примірник замислу підготовки надається до командування СВ ЗС України.

Після затвердження замислу підготовки військ (сил) ОК структурним підрозділом G7 OK відпрацьовується та доводиться до ОВУ, військових частин ОК та органів управління ICCO розпорядження про організацію об'єднаної підготовки військ (сил) на наступний навчальний рік, в якій визначаються:

мета та основні завдання об'єднаної підготовки підпорядкованих військ (сил);

заходи підготовки, які проводяться під керівництвом вищого командування;

порядок об'єднаної підготовки ОВУ та військових частин (підрозділів);

результати підготовки, які очікуються на кінець навчального року;

основні питання всебічного забезпечення об'єднаної підготовки військ (сил);

першочергові заходи щодо організації підготовки до початку нового навчального року $[6,10]$.

У подальшому розробляється перелік заходів об'єднаної підготовки, проведення яких забезпечить досягнення визначеної мети та набуття ОВУ та військовими частинами ОК, органами управління та військовими частинами (підрозділами) ICCO спроможностей щодо виконання завдань відповідно до стандартів підготовки та розраховується потреба коштів для проведення зазначених заходів.

Робота над розробленням плану підготовки військ (сил) ОК починається під час вироблення замислу підготовки, а з його затвердженням він деталізується та наповнюється конкретними заходами підготовки [10].

Під час загального планування підготовки в планувальних документах ОК уточнюються i узгоджуються завдання, цілі і заходи об'єднаної підготовки на новий навчальний рік з урахуванням орієнтовного розподілу видатків на підготовку військ (сил).

При розроблені плану підготовки військ (сил) ОК, група планування підготовки повинна врахувати визначені Генеральним штабом (командувачем СВ) ЗС України навчальнооперативні (навчально-бойові, спеціальні) завдання, які необхідно виконати для набуття оперативних (бойових, спеціальних) спроможностей та перелік заходів підготовки, які сприятимуть набуттю визначених спроможностей. Порядок виконання визначених навчально-оперативних (навчально-бойових, спеціальних) завдань для набуття оперативних (бойових, спеціальних) спроможностей визначає особисто командувач ОК.

у подальшому відпрацьовується планкалендар основних об'єднаних заходів, до якого спочатку вносяться заходи, що проводяться старшими начальниками. Після цього на підставі затвердженого замислу командувача ОК, уточнюються терміни проведення інших заходів підготовки. Особлива увага під час відпрацювання планукалендаря основних заходів відводиться узгодженню за термінами, тематикою та місцем проведення міжвидових (міжвідомчих) заходів підготовки.

Одночасно 3 розробленням Плану підготовки військ (сил) ОК, в структурних підрозділах ОК відпрацьовуються плани підготовки структурних підрозділів на наступний навчальний рік та плани індивідуальної підготовки офіцерського та сержантського (старшинського) складу [10].

У ході розробки Плану підготовки військ (сил) ОК, спільною робочою групою планування уточняється, визначений ГШ ЗС України, конкретний склад сил і засобів, що будуть залучатися до заходів об'єднаної підготовки (навчань, тренувань, занять), їх теми, форми, методи та терміни проведення. Зазначені результати роботи $€$ основою для відпрацювання розпорядження з організації об'єднаної підготовки на навчальний рік. Воно 
розробляється структурним підрозділом G7 OK, погоджується зі керівниками структурних підрозділів ОК та органами управління ICCO.

Тематика заходів об'єднаної підготовки визначається 3 урахуванням оперативних (бойових, спеціальних) спроможностей сил оборони, визначених для набуття В навчальному році.

Форма плану визначається Генеральним штабом ЗС України. Вона містить: титульний аркуш, текст документа, додатки, аркуш обліку внесених змін. Додатки до плану підготовки розробляються структурними підрозділами ОВУ, начальниками родів військ та служб (робочою групою) за напрямами діяльності.
Рішенням командувача ОК перелік додатків до плану підготовки може бути змінений залежно від функціонального призначення, визначених завдань та особливостей підготовки родів військ та спеціальних військ ОК, а також вимог до визначених оперативних (бойових, спеціальних) спроможностей.

Робота в ОВУ при плануванні підготовки військ (сил) ОК може бути організована як послідовним так і паралельним методом.

Варіант проведення основних заходів загального планування підготовки військ (сил) ОК паралельним методом показаний на рисунку $2[7.8,9,10]$.

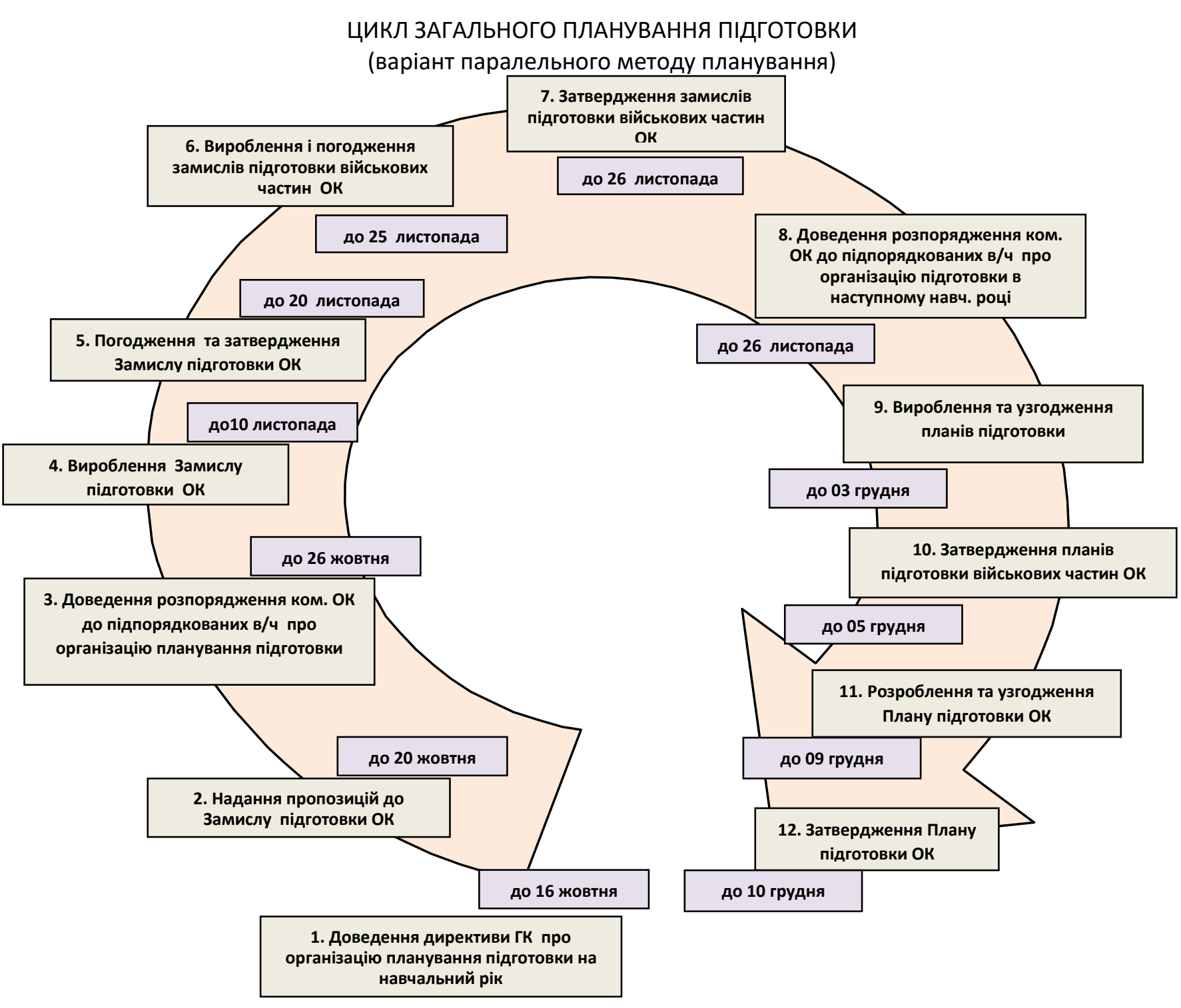

Рисунок 2 - Цикл загального планування підготовки військ (сил) ОК 
Відповідно до вимог Головнокомандувача ЗС України, кінцевим результатом загального планування підготовки військ (сил) ОК повинно бути розроблення наступних плануючих документів:

В оперативному командуванні:

а) розпорядження про організацію планування підготовки на навчальний рік;

б) замисел підготовки на навчальний рік;

в) розпорядження про організацію підготовки у навчальному році;

г) план підготовки на навчальний рік;

д) установчий наказ (в частині що стосується розкладу дня);

є) плани індивідуальної підготовки офіцерського та сержантського (старшинського) складу [7, 10].

У структурних підрозділах ОК:

а) план підготовки на навчальний рік;

б) плани індивідуальної підготовки офіцерського та сержантського (старшинського) складу; в) установчий наказ (в частині що стосується розкладу дня).

План підготовки ОК перед затвердженням обов'язково погоджується - 3 Головним управлінням доктрин і підготовки Генерального штабу ЗС України; 3 Командуванням підготовки СВ ЗС України, начальниками родів (служб) командування СВ ЗС України [10].

План підготовки ОК підписується командувачем ОK і затверджуються командувачем СВ ЗС України.

План підготовки ОК розробляється та оформлюється у двох примірниках. Затверджений другий примірник плану підготовки подається до командування СВ 3С України.

Загальне планування підготовки військ (сил) ОК завершується затвердженням плану підготовки ОК перед початком навчального року.

\section{Висновки}

Ретельно продумане планування підготовки всіх складових сил оборони приведе до суттєвого підвищення рівня їх боєздатності з досягненням і підтриманням визначених спроможностей щодо до виконання покладених на них функціональних завдань. по захисту суверенітету, територіальної цілостності і незалежності України.

\section{Список використаних джерел}

1. Про національну безпеку : Закон України від 21.06.2018 р. № 2469-VIII. Офіційний вісник України. 2018. 20 лип. (№ 55). С. 51.

2. Про ведення в дію Тимчасової доктрини застосування сил оборони держави : наказ Командувача Генерального штабу Збройних Сил України від 31.03.2020 р. № 124.36 c.

3. Доктрина підготовки сил оборони держави : наказ Генерального штабу Збройних Сил України від 21.01.2020 р. № $18.26 \mathrm{c}$.

4. Доктрина організація об'єднаної підготовки сил оборони держави : затв. Нач. Ген. штабу Збройних Сил України від 01.08.2020 p. 34 c.
5. Єдиний перелік (каталог) спроможностей Міністерства оборони України та Збройних Сил України : затв. Мін. оборони України від 28.112017 р. 27 с.

6. Доктрина 3 організації оцінювання (сертифікації) у Збройних Сил України : затв. Нач. Ген. штабу Збройних Сил України від 04.11.2020 р. 34 с.

7. Настанова з бойової підготовки у збройних Сил України : затв. наказом Ген. штабу Збройних Сил України 07.10.2020 p. 57 с.

8. Настанова 3 оперативної підготовки у Збройних Сил України : затв. наказом Ген. штабу Збройних Сил України 13.02.2021p. $45 \mathrm{c}$. 
9. Методичні рекомендації з планування підготовки у Збройних Сил України : затв. наказом Ген. штабу Збройних Сил України 26.09.2020 p. 21 c.

10. Repilo Y., Kharabara V. Partial methodology for assessing the level of methodological training of trainers during combat training of tank brigade during combat readiness. VUZF University. Sofia, 2020. № 1. P. 54-58

11. Khoma V., Bezuhlyi V., Mazurenko I., Procedure planning of the combat training of the interagency formation of the state defense forces. Wydawnictwo Instytutu

Bezpieczeństwa i Rozwoju

Międzynarodowego. Warsaw, 2021. P. 287293.

12. Piekhota, S., \& Kurban, V. (2021). Recommendations for the organization and conduct of individual training of officers of the tactical aviation brigade. Journal of Scientific Papers "Social Development and Security», 11(2), 231-237. DOI: 10.33445/sds.2021.11.2.20

\title{
Методические рекомендации по общему планированию объединенной подготовки войск (сил) оперативного (воздушного, морского) командования
}

\author{
Владимир Баталюк * 1 А; Дмитрий Куприенко ${ }^{28}$; Григориій Тихонов ${ }^{3 \text { A }}$ \\ * Corresponding author: ${ }^{1}$ доцент кафедры, e-mail: 0503172161@ukr.net \\ 2 доктор воен. наук, професор, начальник кафедры, e-mail: dakuprienko@gmail.com \\ 3 канд. воен. наук, старший научный сотрудник, начальник кафедры, e-mail: tikhonov2404@ukr.net \\ А Национальный университет обороны Украины имени Ивана Черняховского, Киев, Украина

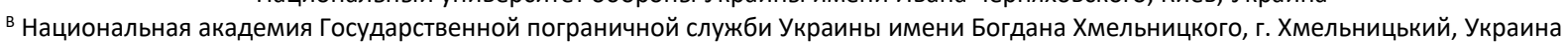

\begin{abstract}
Аннотация
Статья посвящена планированию подготовки органов военного управления и воинских частей, приоритетам деятельности штабов на оперативном и тактическом уровнях управления в связи с переходом на новые структуры (НАТО) органов военного управления ВС Украины. Рассмотрены современные проблемы планирования подготовки в оперативных штабах, входящего в штаб ОК, а планирование боевой подготовки управлений (отделов), подчиненные непосредственно командующему оперативным командованием.
\end{abstract}

Ключевые слова: оперативное (воздушное, морское) командование, планирование объединенной подготовки, план подготовки, способности.

\section{Methodological recommendations for the general planning of the combined training of troops (forces) of the operational (air, sea) command}

\footnotetext{
Vladimir Bataluk * 1 A; Dmytro Kupriyenko ${ }^{2}$; ; Grigory Tikhonov ${ }^{3 \text { A }}$

* Corresponding author: ${ }^{1}$ assistant professor Chief Department of Command of Troops (Forces) in Peacetime, e-mail: $0503172161 @ u k r . n e t$

2 Doctor of military sciences, professor, professor National Academy of the State Border Guard Service of Ukraine, e-mail: dakuprienko@gmail.com ${ }^{3}$ Candidate of Military Sciences, Senior Researcher, Colonel, Chief Department of Command of Troops (Forces) in Peacetime, e-mail: tikhonov2404@ukr.net

A National Defence University of Ukraine named after Ivan Cherniachovskyi, Kyiv, Ukraine

${ }^{B}$ National Academy of the State Border Guard Service of Ukraine named after Bohdan Khmelnytskyi, Khmelnytskyi, Ukraine
}

\section{Abstract}

The article is devoted to the planning of the training of military command and control bodies 
and military units, the priorities of the activities of the headquarters at the operational and tactical levels of command in connection with the transition to new structures (NATO) of military command and control bodies of the Armed Forces of Ukraine. The modern problems of planning training in operational headquarters, which is part of the OK headquarters, and planning of combat training of directorates (departments) subordinate directly to the commander of the operational command are considered.

Keywords: operational (air, naval) command, joint training planning, training plan, capabilities.

\section{References}

1. On national security: Law of Ukraine of June 21, 2018 № 2469-VIII. Official Gazette of Ukraine. 2018. 20 Jul. (№ 55). S. 51.

2. On the implementation of the Provisional Doctrine of the use of state defense forces: the order of the Commander of the General Staff of the Armed Forces of Ukraine from 31.03.2020 № 124. 36 p.

3. The doctrine of training the state defense forces: the order of the General Staff of the Armed Forces of Ukraine from 21.01.2020 № 18.26 p.

4. The doctrine of the organization of joint training of state defense forces: approved. Start. Gene. headquarters of the Armed Forces of Ukraine from 01.08.2020 34 p.

5. Unified list (catalog) of capabilities of the Ministry of Defense of Ukraine and the Armed Forces of Ukraine: approved. Min. of Defense of Ukraine dated November 28, $201727 \mathrm{p}$.

6. Doctrine on the organization of assessment (certification) in the Armed Forces of Ukraine: approved. Start. Gene. headquarters of the Armed Forces of Ukraine from 04.11.2020 34 p.

7. Guidelines for combat training in the Armed Forces of Ukraine: approved. by order of Gen. headquarters of the Armed Forces of
Ukraine 07.10.2020 $57 \mathrm{p}$.

8. Guidelines for operational training in the Armed Forces of Ukraine: approved. by order of Gen. of the Headquarters of the Armed Forces of Ukraine on February 13, $202145 \mathrm{~s}$.

9. Methodical recommendations for training planning in the Armed Forces of Ukraine: approved. by order of Gen. Headquarters of the Armed Forces of Ukraine September 26, $202021 \mathrm{p}$

10. Repilo Y., Kharabara V. Partial methodology for assessing the level of methodological training of trainers during combat training of tank brigade during combat readiness. VUZF University. Sofia, 2020. № 1. P. 54-58

11. Khoma V., Bezuhlyi V., Mazurenko I., Procedure planning of the combat training of the interagency formation of the state defense forces. Wydawnictwo Instytutu Bezpieczeństwa i Rozwoju Międzynarodowego. Warsaw, 2021. C. 287293.

12. Piekhota, S., \& Kurban, V. (2021). Recommendations for the organization and conduct of individual training of officers of the tactical aviation brigade. Journal of Scientific Papers "Social Development and Security", 11(2), 231-237. DOI: 10.33445/sds.2021.11.2.20 